\title{
Evaluation of complications in postoperative of thirdmolar extraction
}

\author{
Layane Maria de Sousa ${ }^{a}$, Leonardo Alonso de Moura ${ }^{a}$, Morgana Marielle de Almeida Costa ${ }^{a}$
}

\begin{abstract}
OBJECTIVE: This study aimed to analyze parameters such as the presence of trismus, facial swelling, postoperative pain, paresthesia of the inferior alveolar and lingual nerve, alveolitis, late bleeding and correct use of prescribed medications. Relating the complication rates with age, gender and proper use of medications prescribed.

METHODS: This study evaluated 20 patients who have gone through removal of third molars, using questionnaires applied by researchers in the postoperative period of seven days in the graduate and professional qualifications Pós-Doc center from April to May/2015.

RESULTS: It was observed that $45 \%$ of the patients had pain, $45 \%$ had trismus, $15 \%$ had paresthesia, $85 \%$ had late light bleeding, $5 \%$ had fever, malaise or discharge from the surgical site and $45 \%$ had facial swelling.

CONCLUSION: The more frequent complications found were pain and late bleeding, with no association between pain and gender and pain and age.
\end{abstract}

Key words: Third molar; Complications; Postoperative

\section{Avaliação das complicações de pós operatório de exodontia de terceiro molar}

\section{RESUMO}

INTRODUÇÃO: Neste trabalho buscou-se analisar parâmetros como a presença de trismo, edema, dor pós-operatória, parestesia dos nervos alveolar inferior e lingual, alveolite, sangramento tardio e uso correto das medicações prescritas. Relacionando as taxas de complicações com idade, gênero e uso correto das medicações prescritas.

METODOLOGIA: Esta pesquisa avaliou 20 pacientes, que passaram pela remoção de terceiros molares, por meio de questionários aplicados pelos pesquisadores no pós-operatório de 7 dias no centro de pós-graduação e qualificação profissional Pós-Doc no período de abril a maio de 2015.

RESULTADOS: Observou-se que $45 \%$ dos pacientes avaliados apresentaram dor, $45 \%$ apresentaram trismo, $15 \%$ apresentaram parestesia, $85 \%$ apresentaram hemorragia leve tardia, $5 \%$ tiveram febre, mal-estar ou saída de secreção no local da cirurgia e $45 \%$ apresentaram edema facial.

CONCLUSÃO: as complicações mais encontradas foram dor e hemorragia tardia, observando não ter associação entre dor e gênero e dor e idade.

Palavras-chave: Terceiro molar; Complicações; Pós-operatório
${ }^{a}$ Centro universitário de saúde, ciências humanas e tecnológicas do Piauí, UNINOVAFAPI, Teresina, PI, Brazil

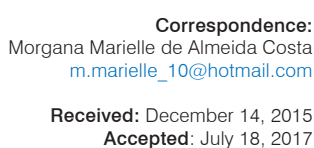

Accepted: July 18,2017

Conflict of Interests: The authors state that there re no financial and personal conflicts of interest that could have inappropriately influenced their work.

Copyright: (c) 2017 De Sousa et al licensee EDIPUCRS.

This work is licensed under a Creative Commons Attribution 4.0 International License. 


\section{INTRODUCTION}

The third molars are the most appointed teeth for removal, and their extraction is one of the most frequently performed practices in the dental clinic. However, the complication rate is small, causing most of the operations happens without any complications [1].

The main indications for these teeth removal includes cases of tissue lesions, periodontal problems, acute or chronic pericoronaritis, caries and idiopathic pain. The prophylactic removal is indicated in some situations for prevention of tumors and cysts, jaw fractures and in consequence of most difficulty of removal with advanced age of the patient [2].

The third molars extraction is associated with low rates of postoperative complications, liketrismus, facial swelling, postoperative pain, dry socket, paresthesia or prolonged anesthesia of the inferior alveolar nerve and lingual. Risk factors for complications include age, gender, medications like antibiotics, corticosteroids or oral contraceptives, smoking, previous infection, periodontitis, poor oral hygiene, surgeon's experience, difficulty of extraction, surgery time, and number of extracted teeth, inadequate irrigation and anesthetic technique [3].

The surgery duration has been associated with the surgeon's experience, severity of impaction and tooth position. Postoperative complications have been associated in many studies with extended operating time [4].

Patients should be warned of the estimated time of surgery and other possible complications before extraction of third molars, based on scientific evidence and preoperative information to help in planning surgery. A good medical history and good planning help in surgery and ensure a better postoperative to the patient [5].

Benediktsdóttir et al. [4] found that younger patients have twice less risks of surgery to be more time-consuming compared to older patients, the proximity to the inferior alveolar canal is also a risk for a longer operation time, the chances double when the tooth is positioned horizontally and has more than one root.

One of the complications commonly found is the trauma caused to both inferior alveolar and lingual nerve, generating prolonged anesthesia or paresthesia of the places where it is verified innervation. A lack of sensitivity is generally reverted spontaneously, but in some cases it may last for over a year and the outcome depends on the type of injury incurred by the nerve and the severity of the inflammation present.The most common cause of trauma to the inferior alveolar nerve (IAN) and the lingual (LN) is a third molar extraction traumatic surgical and the risk factors include the patient's age (over thirty years old), tooth impacted horizontally, radiographic proximity to the inferior alveolar canal and treatment made by graduate students or inexperienced graduate [6].

Several studies have been performed around the world in order to investigate the postoperative complications of third molar extractions and apply the knowledge obtained in dental practice, giving the patient and the professional greater safety in the surgical procedure. The collected data in this study may further contribute both to patients and to the scientific community, in search of a service with less potential trauma to the patient.

\section{METHODS}

The study was conducted after prior approval from the Ethics Committee in Research $(E C R)$ for humans of Faculdade de Ciências Humanas e Tecnológicas do Piauí - UNINOVAFAPI. Under approval number: 1031883. This is an observational analytic cross-sectional study, analyzing statistically the datas found.

Postoperative were analyzed in 20 patients submitted to third molars extraction in the graduate and professional training Pós-Doc Center (Centro de Pós-Graduação e Qualificação Profissional Pós-Doc) after seven days of surgery through questionnaires applied by researchers for each patient.

It was included in the research male and female over 18 years old who had higher or lower maxillary third molar, impacted or fully erupted, indicated to the extraction. It was excluded patients who refused to participate in the survey, under 18 years old and who had no indication to third molars extraction. Patients with decompensated metabolic diseases such as controlled diabetes, kidney disease, leukemia, lymphomas, severe heart disease. Patients with other diseases such as unstable angina pectoris, myocardial infarction, with severe decompensated cardiac arrhythmias, with severe bleeding disorders, such as hemophilia or platelet disorder and pregnant who are in the first or last trimester of pregnancy.

The survey did not bring legal complications because the risks were minimal for the patient. These may be psychological and/or moral. The researchers reported that patients would not be submitted to any experiment, as well as your personal identity will be preserved thus avoiding any kind of intimidation.

The participation of the patient in this study was completely voluntary. The procedures adopted in this study comply with the Ethical Criteria for Research on Human Beings, under the terms set in Resolution No. 466, from December 12, 2012 of the National Health Council, which refers to respect for human dignity and special protection due to participants of scientific research.

It was presented an authorization term of postgraduate cand professional qualifications Pós-Doc, where were data for the period April-May/2015 were collected.

The benefits of this research are both the scientific community and to the patients because watching events in a post-operative extraction of third molars and analyzing the risk factors for complications, it is possible that surgery is better planned and the risks to patients are reduced.

Data were recorded on file developed specifically for this purpose and submitted to data distribution analysis and converted into graphs and charts. 


\section{POST-OPERATIVE EVALUATION QUESTIONNAIRE (AFTER 7 DAYS)}

AGE:

GENDER:

- Are you feeling pain in the surgery region?

( ) Yes ( ) No

- Post operative pain

Moment 1: 24 hours after surgery

\begin{tabular}{|l|l|l|l|l|l|l|l|l|l|l|}
\hline 0 & 1 & 2 & 3 & 4 & 5 & 6 & 7 & 8 & 9 & 10 \\
\hline
\end{tabular}

Moment 2: 7 days after surgery

\begin{tabular}{|l|l|l|l|l|l|l|l|l|l|l|}
\hline 0 & 1 & 2 & 3 & 4 & 5 & 6 & 7 & 8 & 9 & 10 \\
\hline
\end{tabular}

- Do you have difficulty in mouth opening?
( ) Yes
( ) No

- Inter-incisal distance: $\mathrm{mm}$

- Did lack of sensitivity is present or did you feel prolonged anesthesia in the surgery region? ( ) Yes ( ) No

- Was anti-inflammatory or analgesic prescribed?
( ) Yes
( ) No

- Did you use the prescribed drugs correctly?

( ) Yes ( ) No

- Did you have late bleeding?
( ) Yes
( ) 1 day
( ) 2 days
( ) 3 days
( ) More days
( ) No

- Did you have fever, discomfort, or secretion in the surgery site?
( ) Yes
( ) No

- Did you have facial edema?

( ) Yes ( ) No

Data were described adequately and expressed by a computer program (SPSS and Microsoft Office Excel), presented by graphs and tables.

The association test was Fisher's exact test with 5\% significance level.

\section{RESULTS}

The survey was performed with 20 patients, aged between 19 and 49 years old, average age of 25.25 years and standard deviation of 7.99 , of which $12(60 \%)$ were females and $8(40 \%)$ males.

Most patients surveyed (55\%) reported no postoperative pain (7 days), however, among patients who reported pain, the highest prevalence was between women. In relation the difficulty in mouth opening, it was the same as described above, $55 \%$ did not have modification, but among those who reported, there was a higher prevalence in female patients. According to Fisher's exact test, there is no association between the presence of trismus and gender of the patient $(p=0.197)$ and between pain and gender of the patient $(\mathrm{p}=0.670)$.

Relating gender with the complications of facial swelling and late bleeding, it was observed that a minority of surveyed patients showed facial swelling $(45 \%)$, being a complication that happen frequently in women. Late bleeding, however, was one of the most observed complications $(75 \%)$ in both male and female patients. Doing Fisher's exact test it was pointed that there is no association between facial swelling and gender $(\mathrm{p}=1.0)$.

In a parallel comparison between the presence of facial swelling and the correct use or not of prescribed medication, it is observed that only $45 \%$ of patients had this alteration, however, most of them $(80 \%)$ did not correctly used the prescribed medication. Among the patients who used the correct medication $66.67 \%$ did not had face swelling. Through Fisher's exact test it was analyzed that there is no association between medication and facial edema. 
Relating the age of the patients surveyed with the presence of trismus and postoperative pain, it is observed that trismus appeared more in patients who are in the age range from 19 to 24 years. But when relates age with postoperative pain, it is noticed the reverse, as the patients who most reported pain are from 25 or older. Through Fisher's exact test there is no relationship between trismus and the age of the patient $(p=1.0)$ and also there is no relationship between postoperative pain and age $(\mathrm{p}=1.0)$.

Connecting age with the occurrence of facial swelling and late bleeding after surgery it is observed that in younger patients (from 19 to 24 years old), there was a slight prevalence of facial swelling compared to older patients (25 years old or older). In relation to the bleeding it was observed that it was the most frequent complication for patients, appearing in $75 \%$ of young patients and $100 \%$ of older patients. However, Fisher's exact test concludes that there is no association between edema and age $(p=1.0)$.

It has been demonstrated that, in the day of the surgery, among the patients who took the prescribed medication correctly in the moment that they felt pain, most assessed pain level as 8 , on a scale from 0 to 10 . Those who not had the medication, were evaluated with varying levels of pain right after surgery, with no prevalence (levels $0,4,5,7$ and 8 ). At the moment 2 researched, 7 days after surgery, between patients who took prescribed medication correctly, most considered their pain as level 0 . The same was observed in patients who did not take the medication.

Among the patients studied, $3(15 \%)$ had paresthesia or prolonged anesthesia in the surgery region. About the incidence of fever, discomfort or secretion output in the surgical site, only 1 patient (5\%) reported having fever postoperatively and 19 patients $(95 \%)$ did not report this type of complication.

Table 1. Relationship of gender with postoperative pain and trismus. Teresina (PI), 2015.

\begin{tabular}{|c|c|c|c|c|c|c|c|c|}
\hline \multirow{3}{*}{ Gender } & \multicolumn{4}{|c|}{ Postoperative pain (seven days) } & \multicolumn{4}{|c|}{ Trismus } \\
\hline & \multicolumn{2}{|c|}{ Yes } & \multicolumn{2}{|c|}{ No } & \multicolumn{2}{|c|}{ Yes } & \multicolumn{2}{|c|}{ No } \\
\hline & Count & $\%$ & Count & $\%$ & Count & $\%$ & Count & $\%$ \\
\hline Female & 6 & 30,0 & 6 & 30,0 & 7 & 35,0 & 5 & 25,0 \\
\hline Male & 3 & 15,0 & 5 & 25,0 & 2 & 10,0 & 6 & 30,0 \\
\hline
\end{tabular}

Source: Direct search

Table 2. Relationship of gender with facial swelling and late bleeding. Teresina (PI), 2015.

\begin{tabular}{|c|c|c|c|c|c|c|c|c|}
\hline \multirow{3}{*}{ Gender } & \multicolumn{4}{|c|}{ Facial swelling } & \multicolumn{4}{|c|}{ Late bleeding } \\
\hline & \multicolumn{2}{|c|}{ Yes } & \multicolumn{2}{|c|}{ No } & \multicolumn{2}{|c|}{ Yes } & \multicolumn{2}{|c|}{ No } \\
\hline & Count & $\%$ & Count & $\%$ & Count & $\%$ & Count & $\%$ \\
\hline Female & 5 & 25,0 & 7 & 35,0 & 10 & 50,0 & 2 & 10,0 \\
\hline Male & 4 & 20,0 & 4 & 20,0 & 7 & 35,0 & 1 & 5,0 \\
\hline
\end{tabular}

Source: Direct search

Table 3. Facial swelling and use of medications. Teresina (PI), 2015

\begin{tabular}{|c|c|c|c|c|c|c|}
\hline \multirow{3}{*}{$\begin{array}{l}\text { Use of medication } \\
\text { correctly }\end{array}$} & \multicolumn{6}{|c|}{ Facial swelling } \\
\hline & \multicolumn{2}{|c|}{ Yes } & \multicolumn{2}{|c|}{ No } & \multicolumn{2}{|c|}{ Total } \\
\hline & Count & $\%$ & Count & $\%$ & Count & $\%$ \\
\hline Yes & 5 & 33,33 & 10 & 66,67 & 15 & 100,00 \\
\hline No & 4 & 80,00 & 1 & 20,00 & 5 & 100,00 \\
\hline Total & 9 & 45,00 & 11 & 55,00 & 20 & 100,00 \\
\hline
\end{tabular}

Source: Direct search

Table 4. Relationship of age with presence of trismus and postoperative pain. Teresina, PI (2015)

\begin{tabular}{|c|c|c|c|c|c|c|c|c|}
\hline \multirow{3}{*}{ Age } & \multicolumn{4}{|c|}{ Postoperative pain (seven days) } & \multicolumn{4}{|c|}{ Trismus } \\
\hline & \multicolumn{2}{|c|}{ Yes } & \multicolumn{2}{|c|}{ No } & \multicolumn{2}{|c|}{ Yes } & \multicolumn{2}{|c|}{ No } \\
\hline & Count & $\%$ & Count & $\%$ & Count & $\%$ & Count & $\%$ \\
\hline $19-24$ & 4 & 33,3 & 8 & 66,7 & 6 & 50,0 & 6 & 50,0 \\
\hline Over 25 & 5 & 62,5 & 3 & 37,5 & 3 & 37,5 & 5 & 62,5 \\
\hline
\end{tabular}

Source: Direct search 
Table 5. Relationship between age, facial edema and late bleeding. Teresina, PI (2015)

\begin{tabular}{|c|c|c|c|c|c|c|c|c|}
\hline \multirow{3}{*}{ Age } & \multicolumn{4}{|c|}{ Facial swelling } & \multicolumn{4}{|c|}{ Late bleeding } \\
\hline & \multicolumn{2}{|c|}{ Yes } & \multicolumn{2}{|c|}{ No } & \multicolumn{2}{|c|}{ Yes } & \multicolumn{2}{|c|}{ No } \\
\hline & Count & $\%$ & Count & $\%$ & Count & $\%$ & Count & $\%$ \\
\hline $19-24$ & 5 & 47,1 & 7 & 58,3 & 9 & 75,0 & 3 & 25,0 \\
\hline Over 25 & 4 & 50,0 & 4 & 50,0 & 8 & 100,0 & 0 & 0 \\
\hline
\end{tabular}

Source: Direct search

Graph 1. Pain level evaluation of patients by the scale of eleven points 24 hours (time 1) and 7 days (time 2) after surgery concerning the use or not of prescribed medication. Teresina, PI (2015).

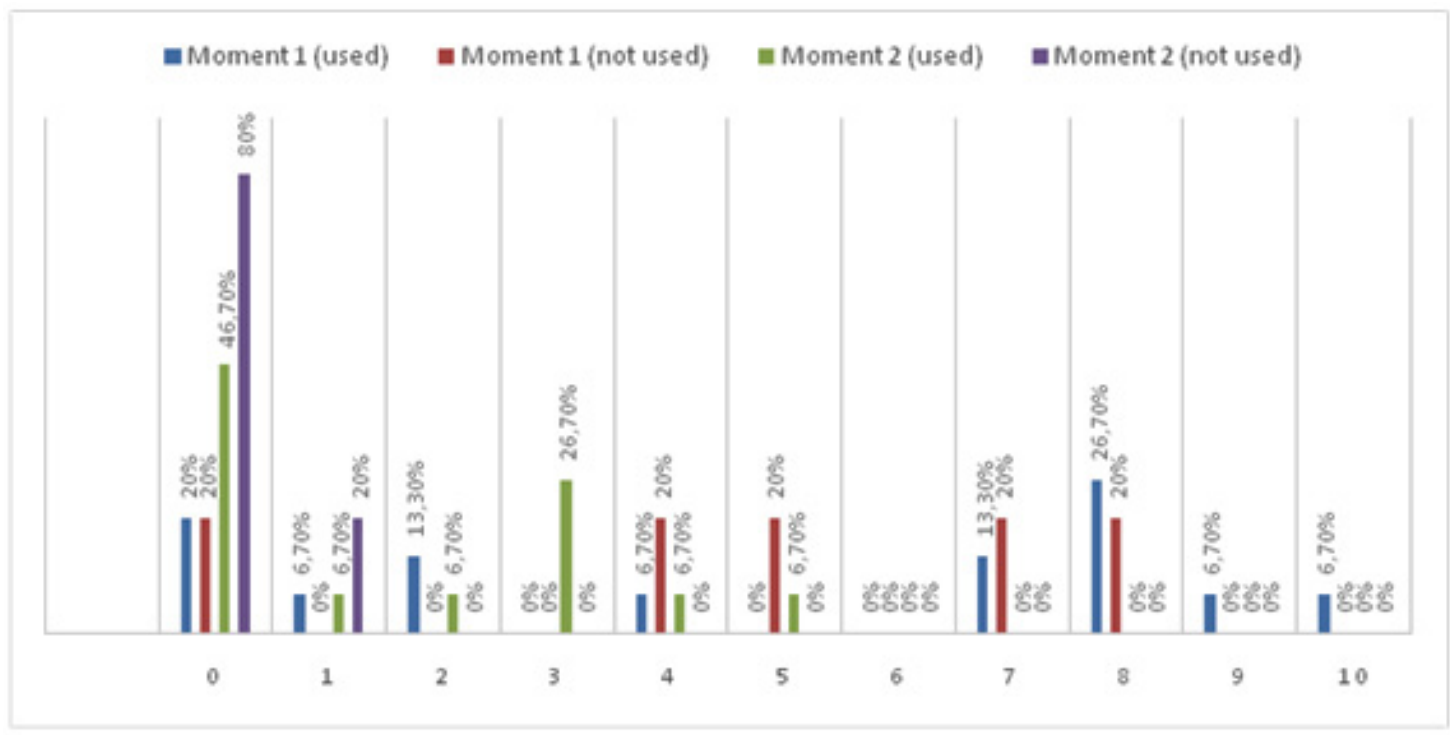

Source: Direct search

\section{DISCUSSION}

The third molars removal is more common in women, found a higher occurrence in several studies. In a study conducted by Negreiros [7] it was found a sample of $55.81 \%$ prevalence of female. Foy et al. [8] performed a study that $54 \%$ of those surveyed were female, while $46 \%$ were male. In the study by Aguiar et al. [9], the majority was female (75\%). These datas are consistent with those found in this study, in which $60 \%$ of the sample was female and $40 \%$ male.

Relating postoperative pain described at the moment of the interview with the gender of the patient, it was observed that $45 \%$ of patients who reported pain, $30 \%$ were female and only $15 \%$ were male. It was different from the studies by Capuzzi et al. [10] and Smith et al. [11], in which they verified that men felt more pain than women in the postoperative period, but consistent with Coulthard et al. [12] that did not observed differences in pain between genders, but concluded that women show more signs of pain when compared to men (Table 1).

After third molars extraction, pain is a very common aspect, however, this is a characteristic difficult to measure because it is subjective, the emotional state of the patient may change your perception of pain and the pain threshold varies for each patient. In this study, we used the 11-point scale in cashto assess postoperative pain in two stages, 24 hours and 7 days after surgery. The average age of the sample was 25.25 years, observing a higher prevalence of this type of surgery in young patients $(60 \%)$, which is consistent with the existing literature. A study by Worrall et al. [13] showed that the average age of patients who underwent third molar extraction were from 21 to 25 years old, and in White's research [14] the average was 21 years old. Relating this scale with the age of the patients, it was observed that among young patients, 33.3\% were feeling pain at the time of evaluation, seven days after extraction, while among adult patients, $62.5 \%$ were feeling pain at the moment of evaluation. It can be observed that there is considerable variation related to the age of the patient, as well as in Capuzzi's research et al. [10] where the younger patients had less pain.

In general, it is known that older patients tend to have more complications after tooth extraction. This feature was observed by Chuang et al. [1] where it was shown that people 
over 25 years are $46 \%$ more likely to have complications, Grossi et al. [15] also stated that older patients have more risk of complications after tooth extractions.

Another complication that can be observed in the postoperative third molar extraction is the trismus, quite common, which is characterized by mouth opening difficulty or inability. A Aguiar's et al. [9] showed that $82.5 \%$ of patients had trismuspost extraction, Colorado-Bonnin et al. [16] observed that $72 \%$ of patients had trismus. However, in this study, differing from the existing literature, it was noted that only $45 \%$ of patients had trismus. Relating this feature with the age of the patients, it was observed that among young patients, $50 \%$ had trismus, whereas in adult patients with this percentage, declined to $37.5 \%$.The disagreement with the literature can be explained because this study included in the sample extractions of superior and lower third molars. The literature generally relates this complication with surgery only lower third molars.

Relating gender with the incidence of trismus in patients questioned, it was observed in this study that there was a rate of $35 \%$ in females and only $10 \%$ in males. In a study of Araújo et al. [17] this was the biggest complication found (34.2\%). There were no reports in the literature that compared gender with incidence of trismus. In patients who reported that had difficulty of mouth opening it was measured the inter-incisor distance with a millimeter ruler and there was a $25-50 \mathrm{~mm}$ variation, similar to the opening found in the postoperative period by Araújo et al. [17] ranging from 19 to $55 \mathrm{~mm}$.

The facial swelling was reported by $45 \%$ of the patients, relating this data to the ages of the patients, it was observed that $47 \%$ of younger patients and $50 \%$ of adults reported facial swelling, showing a small variation in age, which shows that there were no correlations between patient age and the appearance of facial swelling, coinciding with study by Negreiros [7], where there was no relationship between age and facial swelling appearance. Differently from this study, Kim et al. [18] observed that age is the main factor for the occurrence of facial swelling and Yussa and Sugiura [19] showed that patients older than 40 years had moreedema.

The measurement of pain is subjective, whereas facial swelling is a physical change of three-dimensional tissue volume, usually connected with pain, because there is an increase in the tension of tissues. This study demonstrated that the facial swelling is a common postoperative complication after third molar surgery, it was found a $45 \%$ facial swelling rates in the postoperative period of seven days, in contrast with the findings of Negreiros [7] that found a low incidence (26.74\%) (Table 2).

The female patients $(25 \%)$ were more likely to have this complication compared to patients who reported edema (45\%), but half of male patients reported facial swelling. In contrast to the study by Negreiros [7] it was observed a higher swelling index in male patients.

According Chiapasco [20], accidents such as bleeding, are injuries resulting from these surgeries, which can be observed in patients who undergo it. This study demonstrated that $85 \%$ of patients reported bleeding in the postoperative period, in agreement to research conducted by Kato et al. [2], where it was observed that bleeding after surgery is one of the most frequent complications after third molars extraction. In relation to age of the patients it was observed in this study that $75 \%$ of young patients reported bleeding, while among adult patients, bleeding was reported by $100 \%$, which suggests a direct relationship between patient age and bleeding in the postoperative period.

The late bleeding found in this study varies from 1,2 , 3 or more days, having more frequently bleeding report for only 1 day (eight patients) and less frequent bleeding for more than three days (only 1 patient). None of the cases required extra maneuvers, taking self resolution.

About the correct use of medicines with the appearance of postoperative complications of pain and facial swelling, patients who reported having used correctly drug prescriptions, 6 of them denied having pain or facial edema $(30 \%), 4$ of them reported having some level of pain and facial edema (20\%) and only one reported having isolated facial edema (5\%). Patients who reported that did not had the medication correctly, only $1(5 \%)$ did not report the complications mentioned. All the others had pain and swelling, associated or not.

The literature shows that prescription drugs are effective for controlling postoperative pain. Generally the association of a corticoid and an AINE control the postoperative pain, trismus and edema, and is more efficient than the separate administration [21,22].

Using the eleven-point scale in cash was measured the level of pain of patients at moment 1 ( 24 hours after surgery) and moment 2 (postoperative of 7 days) and sought a relation between it and the proper use or not of the drugs during the postoperative period. Statistically analyzing the results (Graphic 1) it was revealed that 75\% (15) of the patients reported taking the medication correctly, among these patients, only $20 \%$ felt no pain and the other $80 \%$ felt some level of pain, prevailing level 8 (4 patients reported). Among the patients who did not take the medication correctly, $20 \%$ reported no pain and $80 \%$ felt some level of pain, not having prevalence of any level. At the moment 2, patients who reported that had taken the drugs correctly, $46.7 \%$ felt no pain (level 0) and 53.3\% reported feeling some level of pain, prevailing level 3. Among the patients who did not use the medication correctly, $80 \%$ reported no pain and $20 \%$ reported pain level 1 . The analysis of these datas showed that there was no direct relationship between the correct use of prescribed drugs and the pain onset in the postoperative period, demonstrating, once again, as well as the studied literature that the subjectivity of the evaluation of pain levels complicates data reliability.

Paresthesia stems from an injury to the nerve and is characterized by the affected nerve insensitivity, causing discomfort to the patient. In this study, it was observed that there was paresthesia in only $15 \%$ of the evaluated patients, 
all women ( 2 patients in the younger group and 1 patient of the adult group) demonstrating that it is not a very frequent complication. These datas are in opposition to research by Benediktsdóttir et al. [4] which showed that only $1.5 \%$ of patients had paresthesia, and all women (2 youth group and 2 in the adult group). This contradiction when compared to existing literature can be explained by the sample size and composition of the same. The present study it was included superior and lower molars, while in the literature paresthesia rate is observed only in the lower third molars.

In this research was evaluated the incidence rate of alveolitis in patients questioned. It was wondered about the appearance of fever, malaise or discharge from the surgical site, only 1 patient reported having fever $(5 \%)$, the others did not report any change in this respect (95\%). Coinciding with study by Bui et al [3], it was observed a rate of $3.4 \%$ in the presence of alveolitis in all extractions performed. As Benediktsdottir et al [4] found a 5.9\% of dry socket index, gender differences with $9 \%$ in women and $1.8 \%$ in men and $2.8 \%$ of generalized infections (with no difference between genres). Haugh et al [23] found a much higher incidence of $12 \%$, the most common complication in their study.

\section{CONCLUSION}

The most frequent complications observed were late pain and bleeding. There was no direct relation between pain and the patient's age and between pain and gender of the patient. Furthermore, trismus rate was lower when compared with the existing literature. Despite the expected, there was no relationship between the level of pain or swelling and the correct use of prescribed medications.

Facial swelling was reported by less than half of the patients and it was not observed relationships between the presence of swelling and the age or gender of patients.

\section{REFERENCES}

1. Chuang SK, Perrott DH, Dodson TB. Age as a risk fatorfor a third molar surgery complications. J Oral MaxillofacSurg. 2007;65:1685-92,. https:// doi.org/10.1016/j.joms.2007.04.019

2. Kato RB, Bueno RBL, Oliveira Neto PJ, Ribeiro MC, Azenha MR. Acidentes e complicações associados à cirurgia dos terceiros molares realizada por alunos de odontologia. Ver. Cir. Traumatol. Buco-Maxilo-Fac. Camaragibe. 2010;10(4):45-54

3. Bui Chi H, Seldin EB, Dodson TB. Types, frequencies, and risk factors for complications after third molar extration. American Association of oral and Maxillofacial surgeons. J oral maxilla fac Surg. 2003;61:1379-89.

4. Benediktsdóttir IS, Wenzel A, Petersen JK, Hintze H. Mandibular third molar removal: Risk indicators for extend operation time, postoperative pain, and complications. Oral Surgery Oral Medicine Oral Pathology Oral Radio Endod. 2014;97(4):438-46. https://doi.org/10.1016/j.tripleo.2003.10.018

5. Zanatta J, Hafner MB, Rolim GS, Moraes ABA. Informação prévia face a face e controle da dor em exodontia de terceiros molares. Rev Dor. São Paulo, 2012;13(3):249-55

6. Kjølle GK, Bjørnland T. Low risk of neurosensory dysfunction after mandibular third molar surgery in patients less than 30 years of age A prospective study following removal of 1220 mandibular third molar.
Oral and Maxillofacial Surgery. 2013;116(4). https://doi.org/10.1016/i. oooo.2013.06.024

7. Negreiros RM. Cirurgia de terceiros molares: avaliação da dor, edema qualidade de vida e variações conforme posição dental. 2010. Dissertação (Mestrado em Odontologia Social) - Faculdade de Odontologia Universidade de São Paulo, São Paulo, 2010. Disponível em: < http:// www.teses.usp.br/teses/disponiveis/23/23148/tde-09062011-110725/> Acesso em: 2014-11-28.

8. Foy SP, Slade GD, Shugars DA, Phillips C, White Jr RP. The impact of third molar symptoms on oral health related quality of life. J Oral Maxillofac Surg. 2003;61(8): 25b-6. https://doi.org/10.1016/S0278-2391(03)00508-1

9. Aguiar ASW, Oliveira ACX, Martins PC, Freire ROM. Avaliação do grau de abertura bucal e dor pós-operatória após a remoção de terceiros molares inferiores retidos. Rev. Cir. Traumatol. Buco-Maxilo-Fac., Camaragibe 2005;5(3):57-64. Disponível em:<http://www.revistargo.com.br/include/ getdoc. php?id=135\&article $=54>$. Acesso em: 05/11/2014

10. Capuzzi P, Montebugnoli L, Vaccaro MA.Extraction of impacted third molars a longitudinal prospective study on factor that affect postoperative recovery. Oral Surg Oral Med Oral Pathol. 1994;77(4):341-3. https://doi. org/10.1016/0030-4220(94)90194-5

11. Pires CP, Ferraz MB, de Abreu MH.TranslationintoBrazilianportuguese, cultural adaptationandvalidationof Oral Health Impact Profile (OIHIP-49). Braz Oral Res. 2006;20(3):263-8. https://doi.org/10.1590/S180683242006000300015

12. Couthard P, Pleuvry BJ, Dobson M, Price M.Behavioral measurement of postoperative pain after oral surgery. $\mathrm{Br} J$ Oral MaxillofacSurg. 2000;38(2):127-31. https://doi.org/10.1054/bjom.1999.0188

13. Worral SF, Riden K, Haskell R, Corrigan AM. UK National Third Molar Project: The initial report. Br J Oral Maxillofac Surg. 1998;36(1):14-8. https://doi.org/10.1016/S0266-4356(98)90740-9

14. White Jr RP, Shugars DA, Shafer DM, Laskin DM, Buckley MJ, Phillips C. Recovery afterthird molar surgery: clinicalandhealthrelatedqualityoflifeoutcomes. J Oral Maxillofac Surg. 2003;61:535-44 https://doi.org/10.1053/joms.2003.50106

15. Grossi GB, Maiorana C, Garramone RA, Borgonovo A, Creminelli L, Santoro F. Assessing Postoperative Discomfort After Third Molar Surgery: A Prospective Study. Oral Maxillofac Surg. 2007;65(5):901-17. https://doi. org/10.1016/j.joms.2005.12.046

16. Colorado-Bonnin M, Valmaseda-Castellon E, Berini-Aytes L, Gay-Escoda C. Quality of life following lower third molar removal. Int J Oral Maxillofac Surg. 2006; 35(4):343-7. https://doi.org/10.1016/j.ijom.2005.08.008

17. Araújo OC, Agostinho CNLF, Marinho LMRF, Rabêlo LRS, Bastos EG, Silva VC. Accidents and complications incidence in third molar surgeries. Rev Odonto UNESP. 2011;40(6):290-295. Disponível em:<wwW. revodontolunesp.com.br/files/v40n6/v40n6a03.pdf>. Acesso em: 06/11/2014

18. Kim JC, Choi SS, Wang SJ, Kim SG. Minor complications after mandibular third molar surgery: type, incidence, and possible prevention.Oral Surg Oral Med Oral Pathol Oral RadiolEndod. 2006;102(2):e4-11.

19. Yuasa $H$, Sugira M. Clinical postoperative findings after removal of impacted mandibular third molars: prediction of postoperative facial swelling and pain based on preoperative variable. BR J Oral Maxillofac Surg. 2004;42(3):209-14. https://doi.org/10.1016/j.bjoms.2004.02.005

20. Chiapasco M, De Cicco L, Marrone G. Side effects and complications associated with third molar surgery. Oral Sug Oral Med Oral Pathol. 1993;76:412-20. https://doi.org/10.1016/0030-4220(93)90005-0

21. Dionne RA, Gordon SM, Rowan J, Kent A, Brahim JS. Dexamethasone suppresses peripheral prostanoid levels without analgesia in a clinical model of acute inflammation. J OralMaxillofacSurg. 2003;61(9):997-1003 https://doi.org/10.1016/S0278-2391(03)00310-0

22. Tiigimae-Saar J, Leibur E, Tamme T. The effect of prednisolone on reduction of complaints after impacted third molar removal. Stomatologija. 2010;12(1):17-22

23. Haugh $\mathrm{RH}$, Perrott $\mathrm{DH}$, Gonzalez ML, Talwar RM. The American association of oral and maxillofacial age-related third molar surgery. J Oral and Maxillofac. Surg. 2005;63(8):1106-14. https://doi.org/10.1016/j. joms.2005.04.022 